\title{
Evidence for Non-linear Pharmacokinetics of Oxytocin in Anesthetized Rat
}

\author{
Valérie Morin ${ }^{1, *}$, Jérôme R.E. del Castillo ${ }^{1, *}$, Simon Authier ${ }^{1,2}$, Norma Ybarra ${ }^{1}$, Colombe Otis ${ }^{1}$, \\ Dominique Gauvin ${ }^{1}$, Jolanta Gutkowska ${ }^{3}$ and Éric Troncy ${ }^{1}$
}

${ }^{1}$ GREPAQ (Groupe de recherche en pharmacologie animale du Québec), Department of veterinary biomedicine, Faculty of veterinary medicine, Université de Montréal, St-Hyacinthe, Quebec. ${ }^{2}$ LAB Research Inc., Laval, Quebec. ${ }^{3}$ Laboratory of Cardiovascular Biochemistry, CHUM Research Center - Hôtel-Dieu, Montreal, Quebec, Canada.

Received, January 16, 2008; Revised, March 14, 2008; Accepted, March 17, 2008; Published March 19, 2008.

\begin{abstract}
Purpose. Because oxytocin (OT) is potentially useful in cardiovascular therapy but has hormonal roles on the cardiovascular and renal systems, we characterized its pharmacokinetic (PK) properties as a function of dose. Methods. A single intravenous bolus of OT was given at doses of $200,300,500,1000,3000,5000$ and $10000 \mathrm{ng} / \mathrm{kg}$ to anesthetized male rats ( $\mathrm{n} \geq 4$ per dose). Blood samples (6) were taken over $72 \mathrm{~min}$ to $150 \mathrm{~min}$, depending on dose. The individual time-courses of plasma OT concentrations were analyzed with a one- or an open two-compartment PK model. Kruskal-Wallis tests (alpha $=0.05)$ were used to compare the PK parameters among groups. Results. At doses up to $500 \mathrm{ng} / \mathrm{kg}$, OT showed a higher median systemic clearance $\left(C L_{T}=0.0624\right.$ $\mathrm{L} /(\min \cdot \mathrm{kg}) ; 0.0622 \pm 0.0228$ as mean $\pm \mathrm{SD}$ value), a higher median central compartment volume of distribution $\left(V_{C}=0.7906 \mathrm{~L} / \mathrm{kg} ; 0.6961\right.$ \pm 0.1754 ), and a lower median elimination half life $\left(t^{1 / 2}(\lambda z) 7.94 \mathrm{~min} ; 9.08 \pm 4.3\right)$ with respect to the higher doses $\left(C L_{T}=0.0266 \mathrm{~L} /(\mathrm{min} \cdot \mathrm{kg})\right.$; $0.0284 \pm 0.0098, V_{C}=0.2213 \mathrm{~L} / \mathrm{kg} ; 0.2227 \pm$ 0.1142 , and $t^{1 / 2}(\lambda z) 21.09 \mathrm{~min} ; 28.36 \pm 21.8$ ), all differences being significant $(p \leq 0.0008)$. Minimal differences were found for the estimates of these PK parameters among the 4 higher OT doses. Conclusion. The PK properties and persistence of exogenous OT are not proportional to dose, therefore this must be accounted for in dosing regimen design for potential cardiovascular therapy.
\end{abstract}

\section{INTRODUCTION}

Oxytocin (OT) is widely used in gynecology and obstetrics to induce labor in women (1) and mare, to combat uterine inertia during parturition in all species, and to stimulate milk letdown in animals presenting agalactia (2). This hormone is present at equal concentrations in the plasma and neurohypophysis of both men and women (3-4). The absence of gender difference suggests other than the traditionally accepted roles for this nonapeptide. Recently, OT has demonstrated the capacity to differentiate embryonic murine stem cells into beating colonies of cardiomyocytes (5), to induce cardiogenic differentiation of adult stem cells (6-7), and to induce mitotic activity in the vascular endothelium (8) as well as cardiomyogenesis (9-10).

Despite its widespread therapeutic use in human beings and animals, the pharmacokinetics (PK) of OT has been examined only in a limited number of studies $(4,11-15)$. The time-course of its plasma concentrations in humans receiving a single i.v. bolus usually is described with an open two-compartment model. The PK data reported up to now for animals resembles that in humans. In goats receiving a single i.v. injection of OT (2000 $\mathrm{ng} / \mathrm{kg}$ ), the plasma concentrations of this hormone also followed a biexponential decay, with an initial (distribution phase) half-life of $1.94 \pm 0.21$ min, a terminal (elimination phase) half-life of $22.3 \pm 0.3 \mathrm{~min}$, and a total body clearance of 0.85 $\pm 0.02 \mathrm{~L} /(\mathrm{h} \cdot \mathrm{kg})$. However, the apparent volume of distribution $\left(V_{\text {area }}\right)$ of OT in goats is $0.46 \pm 0.02$ $\mathrm{L} / \mathrm{kg}$ (12), a three times higher value than in men (15). A study on anesthetized rats receiving a constant infusion of $6040 \mathrm{ng} /(\mathrm{min} \cdot \mathrm{kg})$ reported a systemic clearance of $1.46 \pm 0.22 \mathrm{~L} /(\mathrm{h} \cdot \mathrm{kg})$ and an elimination half-life of $20.70 \pm 1.55 \mathrm{~min}$, as estimated from steady-state plasma concentrations (14).

Corresponding Author: Jérôme R.E. del Castillo, GREPAQ Department of veterinary biomedicine, Faculté de médecine vétérinaire, Université de Montréal, St-Hyacinthe, Quebec, Canada. E-Mail: jerome.del.castillo@umontreal.ca 
From a pharmacodynamic perspective, important effects have been characterized on the cardiovascular and renal functions. Indeed, OT receptors are found in all chambers of the heart and in vascular endothelial cells $(8,16)$, and OT participates in the regulation of cardiovascular functions and volume homeostasis by acting on cardiac receptors to decrease cardiac rate and force of contraction (17-20). These results in isolated rat heart could not be reproduced exactly either in live rats (21) or in other species such as dog (22-24) and human beings (25). Historically, OT showed a natriuretic effect in rat (26-27) but, there is apparent discrepancy in the literature regarding the saliuretic and diuretic properties of OT: some publications report a clear positive effect in rats (28-31), dogs (32-33), and human beings (34), but others report an absent or negative effect in rats $(31,35-36)$, dogs (37-38) and humans (25). Such differences could be associated with the experimental design, in particular with choices regarding the dose, and administration route and method, as well as the degree of hydration/ volemia, gender or species. We hypothesized that at some OT dose level, the magnitude of its associated negative inotropic and chronotropic effects combined with its effects on renal water and electrolyte balance will result in a decrease of its glomerular filtration rate, hence inducing nonlinearity of its urinary clearance and PK response.

Considering the therapeutic potential of OT for cardiac regeneration, precise characterization of the PK profile for each species targeted as an evaluation model is required. PK characterization is needed to optimize dosage regimen, as well as for recognition of speciesspecific pharmacodynamic effects. If the PK of OT is truly dose-dependent, prediction of pharmacodynamic effects in a therapeutic dosage regimen is critical, especially in the context of cardiac failure treatment where adverse pharmacodynamic effects could affect clinical outcome. The objective of the study was to document the dose-linearity of the PK response to i.v.-administered OT bolus, by examining the relationship between dose and the area under the plasma concentration curve over time $(A U C)$, as well as the stationarity of its compartmental PK parameters with respect to dose.

\section{METHODS}

\section{Chemicals}

Synthetic OT was purchased from Peninsula Laboratories (San Carlos, CA, USA). A sterile solution of OT in $0.9 \% \mathrm{NaCl}$ saline was prepared and sterilized by filtration through a $0.45 \mu \mathrm{m}$ polyethersulfone syringe filter (Whatman Inc., Clifton, NJ, USA) before injection. The concentration of OT was adjusted in order to obtain a constant final dose volume of $1 \mathrm{~mL}$. The inhibitors of plasma oxytocinase, pepstatin A and phenylmethanesulfonyl fluoride were purchased from Sigma-Aldrich Chemical (Oakville, ON, Canada). Specific antibodies against OT nonapeptide were a generous gift from Mariana Morris (Wright State University, Dayton, OH, USA). Chemicals for radioimmunoassay (RIA) analyses were at least of RIA grade. All other reagents and solvents were obtained from commercial source.

\section{Animals}

Experiments were performed according to guidelines from the Canadian Council on Animal Care with the approval of the institutional animal care and use committees before initiation of the study. Animal experiments were performed at LAB Research Inc. (Laval, QC, Canada), an AAALAC accredited facility. Adult SpragueDawley male rats (400-700 g; 13-21 weeks old) were obtained from Charles River Laboratories (St-Constant, QC, Canada). To avoid any gender effect, we selected only males. Animals were housed in groups of 2 or 3 in a controlled environment (temperature $21 \pm 3^{\circ} \mathrm{C}$, humidity 30 $70 \%, 12 \mathrm{hr}$ light, $12 \mathrm{hr}$ dark, 10-15 air changes per hr). Laboratory rat chow (Rodent Diet \#2018C, Certified 18\% crude protein, Teklad, Madison, WI, USA) and tap water were given $a d$ libitum.

\section{Animal Preparation}

Animals were anesthetized with isoflurane / oxygen mixture with the vaporizer set at $2 \%$. The animals were kept on heating pads $\left(37^{\circ} \mathrm{C}\right)$. A butterfly needle $(25 \mathrm{G})$ was placed in a tail vein for OT administration. Continuous infusion of Ringer's solution using a syringe pump (AS50, One Baxter Parkway, Deerfield, IL, USA) set at $10 \mathrm{~mL} /(\mathrm{hr} \cdot \mathrm{kg})$ rate was provided to compensate for fluid loss during the experiment. The femoral 
vein was catheterized with an MRE-040 (Braintree Scientific Inc, Braintree, MA, USA) for blood sampling.

\section{Experimental Procedures}

Treatment was assigned randomly to 7 groups of rats ( $\mathrm{n} \geq 4$ each) according to a parallel design. In a first pilot study on isoflurane-anesthetized rats $(n=8)$, several doses of OT were tested for their intensity of cardiovascular effects. The highest OT dose without cardiovascular effect was 300 $\mathrm{ng} / \mathrm{kg}$. Therefore, we selected doses of 200, 300, $500,1000,3000,5000,10000 \mathrm{ng} / \mathrm{kg}$ given as an i.v. bolus. A second pilot study $(n=4)$ was performed to estimate the baseline plasma OT concentration in rats dosed with a volume of saline equal to that to be used for the administration of OT, and to optimize the sampling timepoints (39) to be used in the main study. Blood samples $(1 \mathrm{~mL})$ were taken at the times listed in Table 1, and transferred to chilled EDTA vacuum tubes (Vacutainer, BD, Franklin Lakes, NJ, USA), fortified with $50 \mathrm{nmol}$ pepstatin $\mathrm{A}$, and $100 \mathrm{nmol}$ phenylmethanesulfonyl fluoride. Upon blood collection, tubes were centrifuged for 10 minutes at $1500 \times g$ and $4^{\circ} \mathrm{C}$. Plasma was immediately harvested and stored at $-70^{\circ} \mathrm{C}$ pending analysis.

\section{Analytical Techniques}

Plasma OT concentration was determined with a RIA technique developed in our laboratory, using specific antibodies against OT nonapeptide. Briefly, synthetic OT was labeled with ${ }^{125} \mathrm{I}-\mathrm{Na}$ using the lactoperoxidase method (16). The iodinated tracer was purified by high performance liquid chromatography (LC-600, Shimadzu, Rochester, NY, USA) on a $\mathrm{C}_{18}$ Bondpack column (uBondpack $4.6 \times 250 \mathrm{~mm}$, WAT052860, San Jose, CA, USA). The iodinated OT was eluted with $35 \%$ acetonitrile in $0.1 \%$ trifluoroacetic acid. The RIA was performed in RIA buffer $(50 \mathrm{mM}$ $\mathrm{NaPO}_{4}, \mathrm{pH}$ 7.6; $0.1 \%$ Bovine serum albumine; $0.01 \%$ sodium azide; $0.01 \%$ sodium chloride). All the tubes containing $200 \mu \mathrm{L}$ of sample or standard $\left(0-200 \mathrm{pg} \cdot \mathrm{mL}^{-1}\right)$ were supplemented with $200 \mu \mathrm{L}$ of antibody (1:150 000) solution, and $100 \mu \mathrm{L}$ of ${ }^{125}$ I-OT at a concentration providing 3000 counts per minute. Following a 48h-long incubation at $4^{\circ} \mathrm{C}$, the antibody-bond radioactivity was separated from free radioactivity by supplementing each tube with $1 \mathrm{~mL}$ of dextrancoated charcoal suspension and centrifuging for
$25 \mathrm{~min}$ at $1500 \times \mathrm{g}$ at $4^{\circ} \mathrm{C}$. The radioactivity in the supernatant was then measured with a gamma counter (E5005 Cobra II Auto Gamma, PerkinElmer Packard, Montreal, QC, Canada). Logtransformed data of the standard curve showed linearity within the range of $0.25-200 \mathrm{ng} / \mathrm{L}$, sensitivity of $0.1 \mathrm{ng} / \mathrm{L}$, limit of quantification of $0.1 \mathrm{ng} / \mathrm{L}$, and inter- and intra-assay coefficients of variation of $17.7 \%$ and $6.8 \%$, respectively.

\section{Pharmacokinetic analysis}

Data from the $2^{\text {nd }}$ pilot study was analysed with WinNonlin, version 1.5 (Pharsight corp., Mountain View, CA, USA) to find the optimal sampling times for the main study by graphic inspection of the partial derivatives of the transfer rate micro-constants $k_{10}, k_{12}$ and $k_{21}$ over time (39). The resulting timepoints allowed a minimum of 4 measurable OT plasma concentrations per animal and tested dose. The mean baseline plasma OT concentration measured with the saline control rats was subtracted from the plasma OT concentrations obtained in the main experiment. Then, the individual sets of OT plasma concentrations were examined first with statistical moment PK analysis (40). The systemic clearance $\left(C L_{T}\right)$, apparent volume of distribution $\left(V_{C}\right)$ and steady-state volume of distribution $\left(V_{s s}\right)$ were respectively estimated as:

$$
C L_{T}=\mathrm{Dose} / A U C
$$

Where $A U C$ is the area under the curve of plasma $\mathrm{OT}$ concentration as a function of time.

$$
V_{C}=\text { Dose } / \mathrm{C}_{0}
$$

Where $\mathrm{C}_{0}$ is the initial plasma concentration of $\mathrm{OT}$, as estimated from back-extrapolation of the time-concentration curve after the i.v. bolus dosing.

$$
V_{s s}=C L_{T} / M R T=\text { Dose } \cdot A U M C / A U C^{2}
$$

Where $M R T$ is the mean residence time of OT in the PK system (i.e., the average time the administered OT molecules reside in the body before being eliminated), and $A U M C$ is the area under the momentum curve of the product of plasma OT concentration and time, as a function of time (i.e., the first statistical moment).

These statistical moment estimates of PK parameters were used to derive the initial parameter values for a compartmental PK analysis 
with the ADAPT II software (40). To this end, a set of two ordinary differential equations corresponding to an open two-compartment mammilary model with drug output from the central compartment and first-order drug transfer rates was devised (41). These equations were parameterized with $V_{C}$ and the transfer rate microconstants $k_{10}, k_{12}$, and $k_{21}$ (see below), and solved with maximum likelihood estimation or generalized least square estimation. Goodness of fit to the data was assessed with the Akaike criterion and graphical examination of the residuals (39). After obtaining the best possible fit, systemic clearance $\left(C L_{T}\right)$ was calculated as:

$$
C L_{T}=V_{C} \cdot k_{10}
$$

Where $k_{10}$ is the elimination rate micro-constant from the central compartment. Distribution clearance $\left(C L_{D}\right)$ was:

$$
C L_{D}=V_{C} \cdot k_{12}
$$

Where $k_{12}$ is the transfer rate micro-constant from the central compartment to the peripheral compartment. The apparent volume of the peripheral compartment $V_{P}$ and $V_{S S}$ were calculated as:

$$
\begin{gathered}
V_{P}=V_{C} \cdot k_{12} / k_{21}(6) \\
V_{S S}=V_{C}+V_{P}=V_{C} \cdot\left(1+k_{12} / k_{21}\right)
\end{gathered}
$$

Where $k_{21}$ is the peripheral-to-central compartment transfer rate micro-constant.

\section{Statistical analysis}

The homogeneity of animal weights across treatment groups and the differences between the estimates of $C L_{T}, C L_{D}, V_{C}, V_{S S}$, and terminal half life $\left(t^{1 / 2}\left(\lambda_{z}\right)\right)$ were checked with a Kruskal-Wallis rank test analysis at a 0.05 alpha level, because this non-parametric test is deemed more powerful in cases a small sample (NCSS, Kaysville, UT, USA). In case of an overall significant difference in a given PK parameter, the Dunn's post hoc test was used to determine which dose groups were different from the others. The relationship between $A U C$ and dose was examined with the use of a $3^{\text {rd }}$ order polynomial linear regression model with ordered inclusion of the linear, quadratic, and cubic terms (42), where the statistical significance of the intercept was used to detect departure from dose proportionality, and the statistical significance of the quadratic and cubic terms were used to detect departure from dose linearity (43). Polynomial terms with $p<0.10$ were considered significant.

\section{RESULTS}

No significant difference in body weight was found for the dose groups. The baseline plasma OT concentration in the saline control group was $22.92 \pm 10.89 \mathrm{ng} / \mathrm{L}$ (mean $\pm \mathrm{SD}$ ). Figure 1 shows the individual time-courses of plasma OT concentration in anesthetized rats receiving a single i.v. bolus of $200,500,1000,5000$ or $100000 \mathrm{ng} / \mathrm{kg}$ OT. The decay in plasma OT concentration was clearly monophasic (i.e., a single slope) for the 200 and $500 \mathrm{ng} / \mathrm{kg}$ dose, but was biphasic for all doses greater or equal to 1000 $\mathrm{ng} / \mathrm{kg}$ OT. The time-concentration curves in rats dosed with $300 \mathrm{ng} / \mathrm{kg}$ OT were as for the 200 and $500 \mathrm{ng} / \mathrm{kg}$ dose groups, therefore the open twocompartment PK model was reduced to an onecompartment model for their respective analysis. The average coefficients of variation (CV\%) of their estimated $V$ and $k_{10}$ respectively were $9.1 \%$ and $7.5 \%$, with $95 \%$ confidence intervals (CI) of $[5.8 \%, 12.4 \%]$ and $[4.3 \%, 10.7 \%]$. In contrast, the decay in the time-concentration curves of the 1000,3000 and $10000 \mathrm{ng} / \mathrm{kg}$ dose groups were biphasic as that of the $5000 \mathrm{ng} / \mathrm{kg}$ dose, which enables their analysis with the original twocompartment PK model. The average $\mathrm{CV} \%$ of their estimated $V_{c}, k_{10}, k_{12}$, and $k_{21}$ respectively were $13.1 \%, 12.6 \% 20.0 \%$ and $25.7 \%$, with $95 \%$ CI of $[3.0 \%, 23.3 \%],[3.4 \%, 21.7 \%],[7.3 \%$, $32.7 \%]$, and $[5.4 \%, 46.0 \%]$, respectively. Two of the 8 rats in the $5000 \mathrm{ng} / \mathrm{kg}$ dose group behaved like the ones of the $10000 \mathrm{ng} / \mathrm{kg}$ OT group, which terminal slope $\left(\lambda_{z}\right)$ was not as steep as those of all the other rats that received a dose of 1000, 3000 or $5000 \mathrm{ng} / \mathrm{kg}$ of OT. A bimodal trend occurs from this dosage.

The estimates of $t^{1 / 2}\left(\lambda_{z}\right)$ were significantly different across treatment groups (Kruskal-Wallis test; $p=0.0008$ ). The Dunn's post-hoc test allowed distinguishing the 200, 300 and 500 $\mathrm{ng} / \mathrm{kg}$ OT groups with significantly lower $t^{1 / 2}\left(\lambda_{z}\right)$ values than the ones of the 1000,3000 and 5000 $\mathrm{ng} / \mathrm{kg}$ OT groups (Table 2). With respect to the $t^{1} / 2\left(\lambda_{z}\right)$ in rats dosed $10000 \mathrm{ng} / \mathrm{kg}$ OT, their values were significantly higher than those for all other treatment groups. In addition, the estimated $t^{1} / 2\left(\lambda_{1}\right)$ of the two-compartment model differed from the $t^{1 / 2}\left(\lambda_{z}\right)$ estimates of the one-compartment model, a difference that was significantly affected by dose (Kruskal-Wallis test; $p=0.0004$ ). 
Table 1. Dosing groups, number of rats and timing of post-dosing blood samples used in the study.

\begin{tabular}{cccccccc}
$\begin{array}{c}\text { Dose } \\
\text { (ng/kg) }\end{array}$ & Number of rats & \multicolumn{7}{c}{ Post-dosing sampling number and time (min) } \\
\hline 200 & & $\mathbf{1}$ & $\mathbf{2}$ & $\mathbf{3}$ & $\mathbf{4}$ & $\mathbf{5}$ & $\mathbf{6}$ \\
300 & 4 & 2 & 6 & 12 & 24 & - & - \\
500 & 5 & 2 & 4 & 6 & 36 & 60 & - \\
1000 & 4 & 2 & 6 & 12 & 24 & & - \\
3000 & 4 & 2 & 4 & 6 & 36 & 60 & - \\
5000 & 8 & 2 & 4 & 6 & 36 & 60 & - \\
10000 & 4 & 4 & 12 & 30 & 90 & 120 & 150 \\
\hline
\end{tabular}

Figure 1A

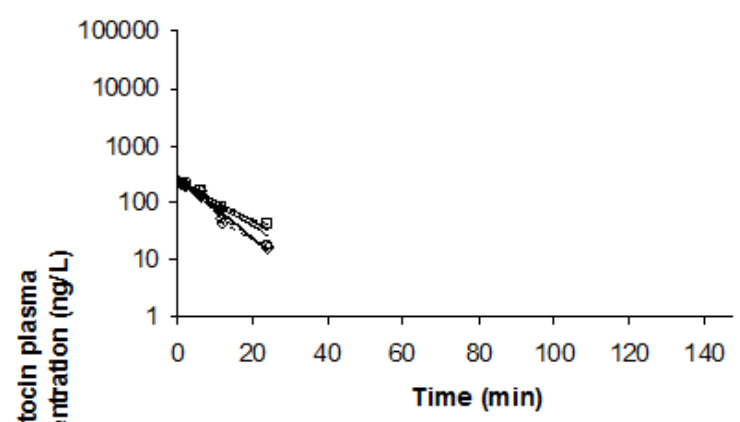

Figure 1C

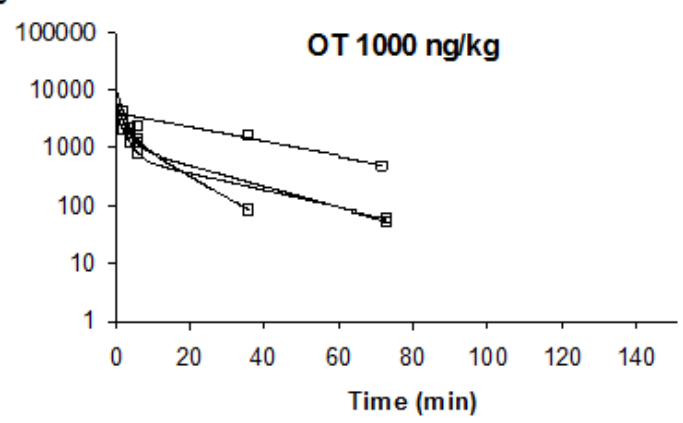

Figure 1E

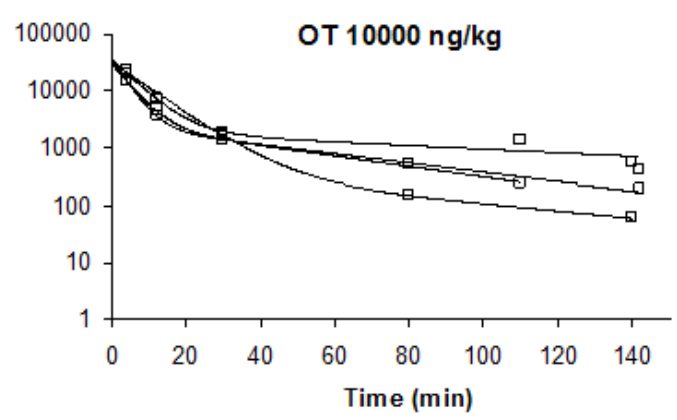

Figure 1B OT $500 \mathrm{ng} / \mathrm{kg}$

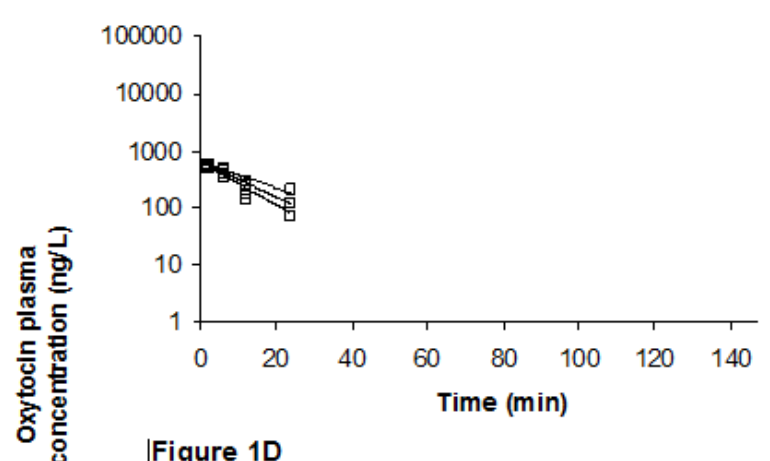

|Figure 1D

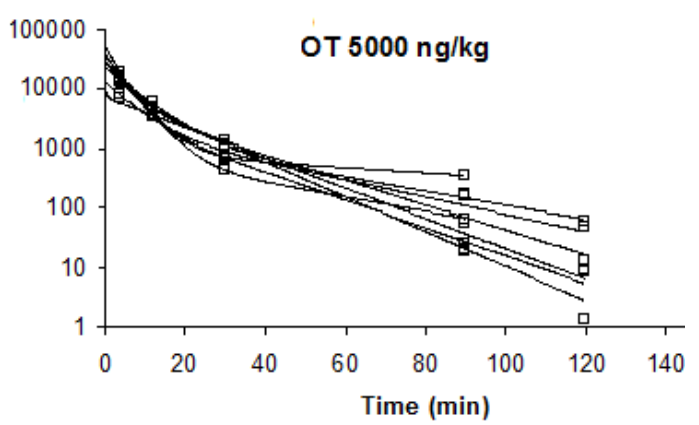

Figure 1. Individual time-courses of dose-normalized, baseline-corrected oxytocin plasma concentrations in rats receiving a single i.v. bolus at a dose of 200,500, 1000,5000 , and $10000 \mathrm{ng} / \mathrm{kg}$. 
The Dunn's post-hoc test revealed significant differences between the $200-500$ $\mathrm{ng} / \mathrm{kg}$ dose groups on one side, and the $1000-$ $5000 \mathrm{ng} / \mathrm{kg}$ dose groups on the other. The $t^{1 / 2}\left(\lambda_{1}\right)$ estimates of rats dosed with $10000 \mathrm{ng} / \mathrm{kg}$ OT were not significantly different from either group, but differences with respect to the 300 and $500 \mathrm{ng} / \mathrm{kg}$ dose groups were closest to significance threshold (i.e., $p$-value between 0.10 and 0.05 ).

The estimates of $C L_{T}$ (Figure 2A) were significantly different among treatment groups $(p$ $=0.0008)$. The post hoc test revealed that the lower dose groups (from 200 to $500 \mathrm{ng} / \mathrm{kg}$ OT) had significantly higher $C L_{T}$ estimates than the higher dose groups: $1000 \mathrm{ng} / \mathrm{kg}(p=0.002), 5000$ $\mathrm{ng} / \mathrm{kg}(p=0.0003)$ and $10000 \mathrm{ng} / \mathrm{kg}(p=0.03)$. Marked variations in $C L_{D}$ were also observed across the range of doses studied: those of the 200 to $500 \mathrm{ng} / \mathrm{kg}$ groups were immeasurable, but the estimates for the 1000 and $5000 \mathrm{ng} / \mathrm{kg}$ OT were significantly different $(p=0.04)$ (Figure $2 \mathrm{~B}$ ).

The estimates of $V_{C}$ (Figure $3 \mathrm{~A}$ ) were significantly different across OT dose groups $(p<$ $0.0001)$. This parameter was significantly higher in the rats dosed 200 to $500 \mathrm{ng} / \mathrm{kg}$ OT, as compared to the higher doses. Differences in $V_{S S}$ were not significant for the doses of 200 to 500 $\mathrm{ng} / \mathrm{kg}$ OT as compared to the 3000 and 10000 $\mathrm{ng} / \mathrm{kg}(p=0.15$; Figure 3B), but were significant between the 3 lower doses and the $1000 \mathrm{ng} / \mathrm{kg}$ ( $p$ $=0.04)$ and $5000 \mathrm{ng} / \mathrm{kg}(p=0.02)$ OT groups.

The estimates of $A U C$ (Table 2) were significantly different among treatment groups, as shown with the polynomial regression analysis $(p$
$<0.0001)$. Significant regression coefficients were recorded for the linear $(p<0.0001)$ and quadratic $(p=0.03)$ terms of dose. It was noteworthy that the quadratic dose term had a negative sign, indicating that the highest OT doses yield AUC values lower than expected from a strict linear relationship.

\section{DISCUSSION}

To our knowledge, the stationarity of OT PK parameters with respect to dose has never been examined when this hormone is given at pharmacologic doses. Because OT has potential usefulness in the regenerative therapy of postischemic myocardial disease, finding an appropriate dosing regimen for this new therapeutic use requires prior knowledge of its dose-concentration relationship. Most drug possess PK parameters that are independent of the administered dose and of the duration of the dosing regimen, which implies that systemic exposure to the drug increases linearly with the administered dose. In the case of OT, cardiovascular and renal functions may be modified by the hormone to a point that its own plasma concentration is a covariate for its disposition PK parameters. Our study allowed confirmation of this hypothesis, as the distribution and clearance PK parameters of OT significantly depended on dose, and the time-course of dosenormalized plasma OT concentration failed to satisfy the superposition principle (40).

Table 2. Median estimates of selected compartmental pharmacokinetic parameters and variables of oxytocin after bolus intravenous administration in rats, as a function of dose.

\begin{tabular}{lccccccc} 
Parameters (units) & $\mathbf{9}$ & \multicolumn{7}{c}{ Dose (ng/kg) } \\
& $\mathbf{2 0 0}$ & $\mathbf{3 0 0}$ & $\mathbf{5 0 0}$ & $\mathbf{1 0 0 0}$ & $\mathbf{3 0 0 0}$ & $\mathbf{5 0 0 0}$ & $\mathbf{1 0 0 0 0}$ \\
\hline Number of compartments & 1 & 1 & 1 & $2^{*}$ & 2 & 2 & 2 \\
$C L_{T}$ & $0.0825^{\mathrm{a}}$ & $0.0417^{\mathrm{a}}$ & $0.0624^{\mathrm{a}}$ & $0.0266^{\mathrm{b}}$ & $0.0370^{\mathrm{a}}$ & $0.0245^{\mathrm{b}}$ & $0.0333^{\mathrm{b}}$ \\
$(\mathrm{L} /(\mathrm{min} \cdot \mathrm{kg}))$ & & & & & & & \\
$C L_{D}$ & $\mathrm{~N} / \mathrm{D}$ & $\mathrm{N} / \mathrm{D}$ & $\mathrm{N} / \mathrm{D}$ & $0.03860^{\mathrm{a}}$ & $0.02561^{\mathrm{a}}$ & $0.00858^{\mathrm{b}}$ & $0.02077^{\mathrm{a}}$ \\
$(\mathrm{L} /(\min \cdot \mathrm{kg}))$ & & & & & & & \\
$V_{C}(\mathrm{~L} / \mathrm{kg})$ & $0.8091^{\mathrm{a}}$ & $0.4878^{\mathrm{a}}$ & $0.8076^{\mathrm{a}}$ & $0.1346^{\mathrm{b}}$ & $0.0989^{\mathrm{b}}$ & $0.1384^{\mathrm{b}}$ & $0.2748^{\mathrm{b}}$ \\
$V_{S S}(\mathrm{~L} / \mathrm{kg})$ & $0.8091^{\mathrm{a}}$ & $0.4878^{\mathrm{a}}$ & $0.8123^{\mathrm{a}}$ & $0.3459^{\mathrm{b}}$ & $0.4515^{\mathrm{a}}$ & $0.3455^{\mathrm{b}}$ & $0.9760^{\mathrm{a}}$ \\
$A U C(\mathrm{~h} \cdot \mathrm{ng} / \mathrm{L})$ & $2219^{\mathrm{a}}$ & $8709^{\mathrm{b}}$ & $6742^{\mathrm{b}}$ & $36529^{\mathrm{c}}$ & $80087^{\mathrm{d}}$ & $200792^{\mathrm{e}}$ & $296439^{\mathrm{e}}$ \\
$t^{1 / 2}\left(\lambda_{I}\right)(\mathrm{min})$ & $\mathrm{N} / \mathrm{D}$ & $\mathrm{N} / \mathrm{D}$ & $\mathrm{N} / \mathrm{D}$ & $1.34^{\mathrm{y}}$ & $1.84^{\mathrm{y}}$ & $3.51^{\mathrm{y}}$ & $4.06^{\mathrm{x}, \mathrm{y}}$ \\
$t^{1 / 2}\left(\lambda_{z}\right)(\mathrm{min})$ & $6.92^{\mathrm{a}, \mathrm{x}}$ & $9.38^{\mathrm{a}, \mathrm{x}}$ & $9.27^{\mathrm{a}, \mathrm{x}}$ & $18.22^{\mathrm{b}}$ & $20.14^{\mathrm{b}}$ & $17.63^{\mathrm{b}}$ & $42.01^{\mathrm{c}}$ \\
\hline & & &
\end{tabular}

Legend: ${ }^{\mathrm{a}, \mathrm{b}, \mathrm{c}}$ Results of dose groups with different superscripts statistically differ $(p<0.05) ;{ }^{\mathrm{x}, \mathrm{y}}$ Results of dose groups with different superscripts significantly differ $(p<0.05)$; N/D not determined; ${ }^{*}$ One subject was best fit with onecompartment PK model. 


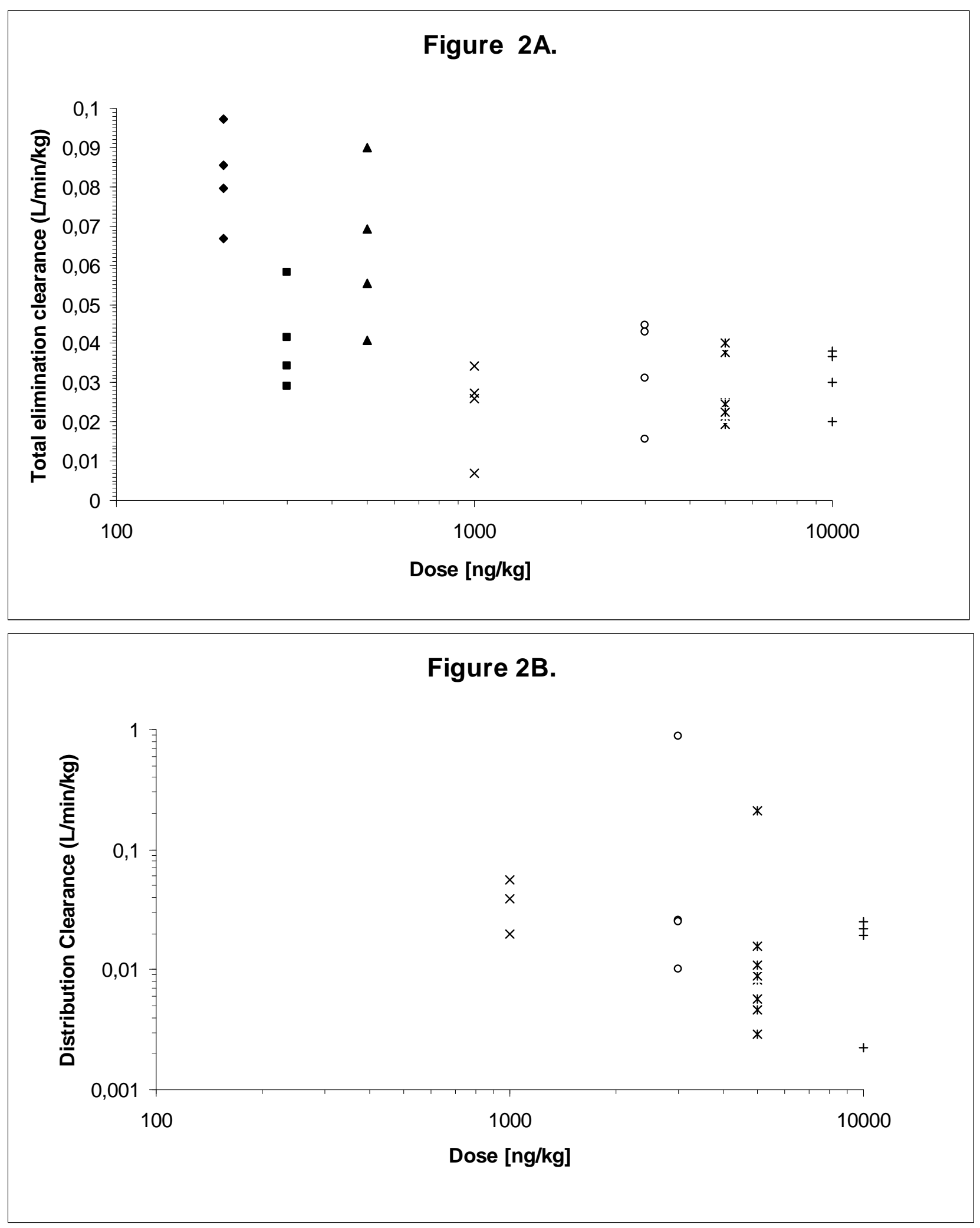

Figure 2. Elimination (A) and distribution (B) clearances of oxytocin in rats individually dosed with a single i.v. bolus, as a function of the administered dose. 

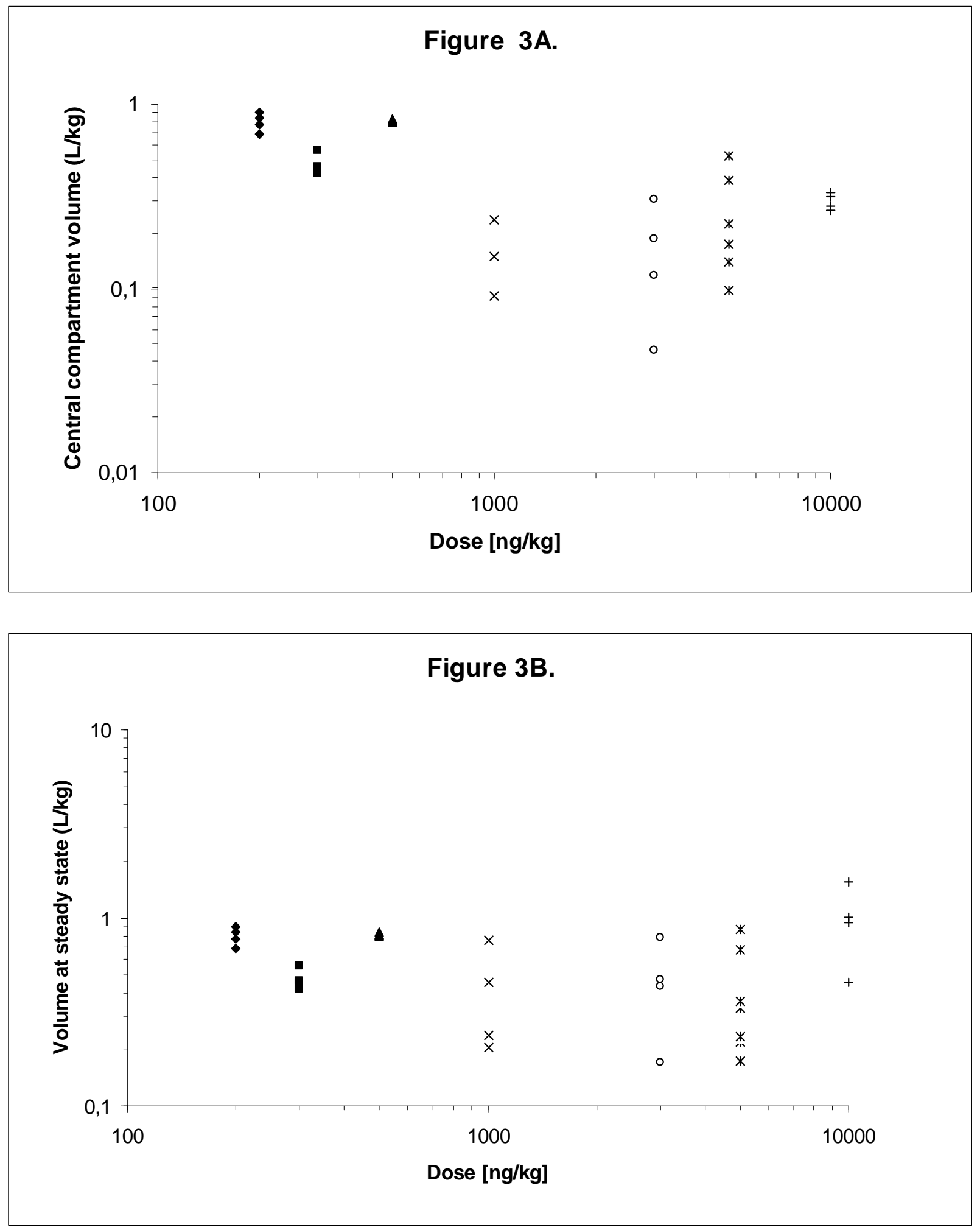

Figure 3. Apparent volumes of the central compartment (A) and at steady state (B) for oxytocin in rats individually dosed with a single i.v. bolus, as a function of the administered dose.

Studies reporting the PK of OT after an i.v. bolus all used an open two-compartment model to describe the time-course of its plasma concentration $(12,14-15,44)$. Another study where 
rats were infused at a constant rate also reported a two-phase decay after the infusion was stopped (45). In our study, a two-compartment open model best described the time-course of plasma OT concentration at doses of $1000,3000,5000$ and $10000 \mathrm{ng} / \mathrm{kg}$, but that of the 200,300 and 500 $\mathrm{ng} / \mathrm{kg}$ OT doses was best described with the onecompartment model (Figure 1). It could be argued that numerical identification of the peripheral compartment was not possible for the lower doses because an inadequate sampling schedule was used. If this were true, implying that the recorded slope corresponds to the distribution process and a terminal slope with $t^{1 / 2}\left(\lambda_{Z}\right)$ of at least $18 \mathrm{~min}$ (Table 2) would be found by extending our sampling schedule, plasma OT concentration in rats dosed with $300 \mu \mathrm{g} / \mathrm{kg}$ drug should fall within the analytical range of our RIA assay $(0.25-200$ $\mathrm{ng} / \mathrm{L}$ ) for at least 60 minutes, and a similar finding would be recorded for the 200 and $500 \mathrm{ng} / \mathrm{kg}$ dose groups. But all rats in the $300 \mathrm{ng} / \mathrm{kg}$ dose group had plasma OT concentrations below the limit of detection at $60 \mathrm{~min}$. In addition, the onecompartment PK model fitted closely to plasma OT concentrations measured in the three lowest dose groups: the choice of this model over the other one was unambiguous, its $\mathrm{r}^{2}$ values averaged 0.95 and its PK parameters were accurately estimated (i.e., with $\mathrm{CV} \%<10.5 \%$ ). These results are inconsistent with the presence of a second, shallower slope in the PK profiles of the $200-$ $500 \mathrm{ng} / \mathrm{kg}$ OT dose groups, as the plasma concentrations associated with this additional slope would considerably affect the goodness of fit, $r^{2}$ value and accuracy of estimated PK parameters. In conclusion, our strategy of devising an optimal sampling schedule (i.e., a schedule that would minimize the error at estimating the parameters of the PK model) based on the results of the pilot experiment allowed minimizing the loss of information associated with the use of restricted sampling schedule. As the adequacy of the sampling schedule has been assessed, the changes in the time-course of plasma OT concentration may be interpreted as hindrance of the PK processes of distribution and elimination as a consequence of the combined effects of OT on the cardiovascular and renal systems. Noteworthy, the increase in AUC as a function of dose was slightly but significantly curvilinear, and the time-course of the dosenormalized plasma OT concentrations failed to satisfy the superposition principle. Indeed, the graphical assessment of the time-course of dosenormalized plasma OT concentrations revealed three items strongly suggestive of nonlinear PK response. First, the PK profiles were markedly affected by the administered dose (Figure 1), and the estimated $t / 2\left(\lambda_{Z}\right)$ of the three lowest OT doses significantly differed from the half-lives of the initial and terminal slopes of the four highest OT doses (Table 2). Second, the duration of the distribution phase in rats dosed with $\geq 1000 \mathrm{ng} / \mathrm{kg}$ was visibly shorter than the duration of measurable plasma concentrations in rats dosed with the three lowest OT doses (Figure 1). Third, as compared to rats receiving the three lowest OT doses, the dose-normalized plasma OT concentrations in rats dosed $\geq 1000 \mathrm{ng} / \mathrm{kg}$ were higher during the whole sampling period (data not shown). Yet, we must point out that the aim of this study was to document dose-related changes in the structure of the PK system of OT, not to build a suitable mechanistic PK model for this hormone. This task would have required a different study design, e.g., with a more intensive sampling schedule and the simultaneous monitoring of the renal and cardiovascular functions. Therefore, the compartmental PK models used here are models of data, which are adequate to fulfill our study objectives and generate specific hypotheses about the PK system of OT, but cannot be used to test these hypotheses because the results would be biased by model misspecification. Nevertheless, the dose-related changes in compartmental PK parameters reported here should provide insight to the cardiovascular and renal effects of OT in rats.

The compartmental PK analysis first revealed that the systemic clearance of OT significantly decreased when administered at doses of 1000,5000 , and $10000 \mathrm{ng} / \mathrm{kg}$, as depicted in Figure 2. Those results indicate that the elimination process of the drug is faster (between 1.5 and 3 times) at doses under 500 $\mathrm{ng} / \mathrm{kg}$ OT and is considerably reduced at 1000 $\mathrm{ng} / \mathrm{kg}$ and above, but tends to stabilize when that plasma level corresponding to the $1000 \mathrm{ng} / \mathrm{kg}$ dose is reached. In the case of a drug with linear kinetics, $C L_{T}$ is the proportionality constant that relates plasma drug concentration to its rate of elimination. The OT is eliminated both by renal filtration (46) and metabolism by oxytocinase (47-48). Prior to hydrolysis by this enzyme (EC 3.4.11.3) OT molecule must bind to its receptor on the external surface of the endothelial cell membrane, which afterwards is internalized via the classic clathrin-mediated pathway (49) and eventually recycled onto the cell surface (46). In 
addition, OT binding sites have been found in the macula densa and thin Henle's loop of the rat kidney (50), which could mediate dual effects on renal filtration and reabsorption (see below). The dose-related decrease in $C L_{T}$ suggest a saturation of the pool of OT receptors and/or oxytocinase molecules, with a plateau reached at the dose of $1000 \mathrm{ng} / \mathrm{kg}$ OT, or a decrease in renal excretion induced by OT at that dose. We will report in a separate communication the results of a study that examined the effects of OT on renal function. The results on $C L_{D}$ are also suggestive of such saturation phenomenon with estimates being not measurable on 200 to $500 \mathrm{ng} / \mathrm{kg}$ OT groups, while being quite homogenous between groups with higher doses: Only a marginally significant $(p=$ 0.04 ) difference was noted between the 1000 and $5000 \mathrm{ng} / \mathrm{kg}$ OT groups for this parameter.

Second, it was noteworthy to find that the median $V_{C}$ decreased abruptly at exogenous OT doses exceeding $500 \mathrm{ng} / \mathrm{kg}$, and its interindividual variability considerably increased (Figure 3). Similar changes were recorded for $V_{S S}$, although median values did not decrease with the OT dose as much as that of $V_{C}$. Because $V_{S S}$ is the sum of the volumes of $V_{C}$ and $V_{P}$, these combined findings imply a concurrent increase in $V_{P}$. This change in the structure of the PK system strongly suggests that $V_{P}$ represents the population of receptors/enzymes where OT could bind on the vascular bed. The OT receptors of the external surface of the endothelium cell membrane are structurally identical to the uterine and mammary OT receptors (8). These receptors, present in limited number, appear to have saturated at the plateau dose of $1000 \mathrm{ng} / \mathrm{kg}$ OT. At doses below $1000 \mathrm{ng} / \mathrm{kg}$ OT, as supported by our PK analysis, the pool of unoccupied OT receptors/enzymes would exceed the number of OT molecules available for binding, and the peripheral compartment may act predominantly as an elimination site. That is, the activity of oxytocinase in the peripheral compartment greatly exceeds the rate of transfer of OT back to the central compartment; therefore, the body behaves as a kinetically homogeneous system that could be described with a one-compartment open model. At higher doses, the peripheral metabolic (oxytocinase) pathway saturates, which would restrict the availability of unoccupied OT receptors, hence forcing the peripheral compartment to behave more as a distribution site. Since OT binding to its receptor activates the translocation of oxytocinase and leads to peptide degradation, it would be interesting to quantify
OT degradation metabolites. This measurement would represent a direct assessment of the apparent $V_{p}$. Unfortunately, no study evaluating OT metabolites is reported yet.

Third, as the OT dose increases and the oxytocinase pathway progressively saturated, it is likely that the rate of recycling of OT receptors decreased, which restricted the pool of unoccupied receptors sufficiently to delay the equilibrium between the two compartments $\left(V_{c}\right.$ and $V_{p}$ ) of the PK system. This delay in homogenization resulted in the development of a distribution phase in the time-course of plasma OT concentration, which slope is $\lambda_{1}$ and PK parameter is $C L_{D}$.

Fourth, our estimated $C L_{T}$ and $t^{1 / 2}\left(\lambda_{z}\right)$ recorded for the doses of $1000 \mathrm{ng} / \mathrm{kg}$ OT or higher are compatible with those previously reported in the literature for human $(4,11,15)$, goat $(12)$ and rat (14), with $C L_{T}$ around $1-1.5 \mathrm{~L} /(\mathrm{h} \cdot \mathrm{kg})$ and $t^{1 / 2}\left(\lambda_{z}\right)$ around $20 \mathrm{~min}$. Interestingly, the terminal slope $\lambda_{z}$ in the $10000 \mathrm{ng} / \mathrm{kg}$ OT group and in 2 individuals receiving $5000 \mathrm{ng} / \mathrm{kg}$ (Figure 1B and Table 2) were more than twofold slower (42 $\mathrm{min}$ ) than the other groups (Table 2). This could be associated, at least in part, with the onset of changes in the renal function following exposure to OT. Indeed, a study in conscious male rats found that $1000 \mathrm{ng}$ i.v. injection of OT induced a $+22 \%$ temporary (5 min duration) increase in mean systemic arterial blood pressure associated to a decrease in heart rate $(-20 \%)$ and contractility $(-15 \%)$ (51). Due to the short duration of cardiovascular effects, their implication on PK parameters dose-dependency is probably limited, if any. Moreover, saliuretic and diuretic/antidiuretic effects of OT have been demonstrated in rats $(29-31,36)$. If the natriuretic effect of OT is relatively constant between rat studies, it was hypothesized that low doses of OT induce diuresis via binding on OT receptor (or a non- $\mathrm{V}_{1 \mathrm{a}}$ non- $\mathrm{V}_{2}$ vasopressin receptor) stimulating an increase in intracellular calcium (52), and high doses of OT induce antidiuresis via binding on $\mathrm{V}_{2}$ vasopressin receptor stimulating a $\mathrm{G}_{\mathrm{s}}$ protein, cyclic AMP release and aquaporine- 2 opening $(53,54)$. As stated above, these renal effects are highly variable, not only with the OT dose and way of administration, but also with the model: i.v. constant rate infusion of OT induced natriuresis and antidiuresis in dogs (38), and antinatriuresis and antidiuresis in humans (25). Consequently, we could propose a dosedependent interference of these pharmacodynamic 
effects on the PK of OT. Also, a tubuloglomerular reflex in response to increased natriuresis could lead to a reduction in the glomerular filtration rate. As a result, the elimination rate for this 1007 Dalton nonapeptide through the glomerular capillaries would be directly reduced and affect the PK elimination parameters. Our data suggests that the saturation of the endothelial receptors, of the oxytocinase activity added with a direct antidiuretic effect and the possible negative feedback of blood perfusion and kidney glomerular filtration rate for fluid homeostasis, explain the diminution of $C L_{T}$ and the increased elimination half-life observed in animals receiving up to 1000 $\mathrm{ng} / \mathrm{kg}$ OT.

\section{CONCLUSION}

This study showed the non-linearity of PK of OT in rats and proposed several hypotheses to explain this unique PK profile. A deeper understanding of the PK behavior, particularly in relation with the metabolism of the peptide, is needed to confirm underlying mechanisms. Investigations of $\mathrm{PK}$ linearity in other species and studies of OT pharmacodynamics on volume homeostasis are also justified. The proof of non-linearity warrants important precautions in the therapeutic use of OT.

\section{ACKNOWLEDGMENTS}

We are grateful to $\mathrm{LAB}$ Research Inc. for supplying the animals, materials and installations, to Marianna Morris for supplying the OT antibody and the Canadian Institutes of Health Research and the Heart and Stroke Foundation of Canada - New Emerging Team (\#108291) program, for their precious financial support.

\section{REFERENCES}

[1]. Dudley DJ. Oxytocin: use and abuse, science and art. Clin Obstet Gynecol, 1997; 40:516524.

[2]. Al-Eknah MM, Homeida AM. A review of some aspects of the pharmacology of oxytocin in domestic animals. Vet Res Commun,1991; 15:45-55.

[3]. Ashton N, Balment RJ. Sexual dimorphism in renal function and hormonal status of New Zealand genetically hypertensive rats. Acta Endocrinol (Copenh), 1991; 124(1):91-97.

[4]. Leake RD, Weitzman RE, Fisher DA. Pharmacokinetics of oxytocin in the human subject. Obstet Gynecol, 1980; 56(6):701-704.
[5]. Paquin J, Danalache BA, Jankowski M, McCann SM, Gutkowska J. Oxytocin induces differentiation of P19 embryonic stem cells to cardiomyocytes. Proc Natl Acad Sci U S A; 2002, 99(14):9550-9555.

[6]. Jankowski M, Danalache BA, Wang D, Bhat P, Hajjar F, Marcinkiewicz M, Paquin J, McCann SM, Gutkowska J. Oxytocin in cardiac ontogeny. Proc Natl Acad Sci U S A; 2004; 101:13074-13079.

[7]. Matsuura K, Nagai T, Nishigaki N, Oyama T, Nishi J, Wada H, Sano M, Toko H, Akazawa H, Sato T, Nakaya H, Kasanuki H, Komuro I. Adult cardiac Sca-1-positive cells differentiate into beating cardiomyocytes. J Biol Chem, 2004; 279:11384-11391.

[8]. Thibonnier T, Conarty DM, Preston JA, Plesnicher CL, Dweik RA, Erzurum SC. Human vascular endothelial cells express oxytocin receptors. Endocrinology, 1999; 140(3):13011309.

[9]. Jankowski M, Danalache BA, Gutkowska J. Cterminal oxytocin peptides induce cardiomyogenesis. [Abstract P112] Hypertension, 2005; 46(5):851.

[10]. Danalache BA, Paquin J, Donghao W, Grygorczyk R, Moore JC, Mummery CL, Gutkowska J, Jankowski M. Nitric oxide signaling in oxytocin-mediated cardiomyogenesis. Stem Cells, 2007; 25(3):679688 .

[11]. Seitchik J, Amico J, Robinson AG, Castillo M. Oxytocin augmentation in dysfunctional labor IV. Oxytocin pharmacokinetics. Am J Obstet Gynecol, 1984; 150(3):225-228.

[12]. Homeida AM, Cooke RG. Biological half-life of oxytocin in the goat. Res Vet Sci, 1984; 37:364365.

[13]. Thornton S, Davison JM, Baylis PH. Effect of human pregnancy on metabolic clearance rate of oxytocin. Am J Physiol, 1990; 259:R21-R24.

[14]. Lundin S, Broeders A, Ohlin M, Hansson K, Bengtsson H-I, Trojnar J, Melin P. Pharmacokinetic and pharmacologic properties of antiuterotonic oxytocin analogs in the rat. J Pharmacol Exp Ther, 1993; 264(2):783-788.

[15]. De Groot ANJA, Vree TB, Hekster YA, Pesman GJ, Sweep FCGJ, Van Dongen PJW, Van Roosmalen J. Bioavailability and pharmacokinetics of sublingual oxytocin in male volunteers. J Pharm Pharmacol, 1995; 47:571575.

[16]. Jankowski M, Hajjar F, Al Kawas S, Mukaddam-Daher S, Hoffman G, McCann SM, Gutkowska J. Rat heart: A site of oxytocin production and action. Proc Natl Acad Sci U S A, 1998; 95:14558-14563.

[17]. Favaretto ALV, Ballejo GO, AlbuquerqueAraújo WIC, Gutkowska J, Antunes-Rodrigues J, McCann SM. Oxytocin releases atrial 
natriuretic peptide from rat atria in vitro that exerts negative inotropic and chronotropic action. Peptides, 1997; 18(9):1377-1381.

[18]. Gutkowska J, Jankowski M, Lambert C, Mukaddam-Daher S, Zingg HH, McCann SM. Oxytocin releases atrial natriuretic peptide by combining with oxytocin receptors in the heart. Proc Natl Acad Sci U S A, 1997; 94:1170411709.

[19]. Gutkowska J, Jankowski M, Mukaddam-Daher S, McCann SM. Oxytocin is a cardiovascular hormone. Braz J Med Biol Res, 2000; 33(6):625-633.

[20]. Mukaddam-Daher S, Yin Y-L, Roy J, Gutkowska J, Cardinal R. Negative inotropic and chronotropic effects of oxytocin. Hypertension, 2001; 38:292-296.

[21]. Petersson M, Alster P, Lundeberg T, UvnäsMoberg K. Oxytocin causes a long-term decrease of blood pressure in female and male rats. Physiol Behav, 1996; 60(5):1311-1315.

[22]. Nakano J, Fisher DR. Studies on the cardiovascular effects of synthetic oxytocin. J Pharmacol Exp Ther, 1963; 142:206-214.

[23]. Armour JA, Yuan BX, Butler CK. Cardiac responses elicited by peptides administered to canine intrinsic cardiac neurons. Peptides, 1990; 11(4):753-761.

[24]. Neath PJ, Brown DC, Hughes D, Perkowski SZ. The hemodynamic effects of intrathecal oxytocin in normal dogs. Vet Surg, 2000; 29:272-277.

[25]. Rasmussen MS, Simonsen JA, Sandgaard NCF, Høilund-Carlsen PF, Bie P. Effects of oxytocin in normal man during low and high sodium diets. Acta Physiol Scand, 2004; 181:247-257.

[26]. Fraser AM. Actions of oxytoxic hormone of pituitary gland on urine secretion. J Physiol, 1942; 101:238-251.

[27]. Sawyer WH. Posterior pituitary extracts and excretion of electrolytes by the rat. Am J Physiol, 1952; 16:583-87.

[28]. Chan WY, Du Vigneaud V. Natriuretic, diuretic and anti-arginine-vasopressin (ADH) effects of two analogs of oxytocin: [4-leucine]-oxytocin and [2,4-diisoleucine]-oxytocin. J Pharmacol Exp Ther, 1970; 174(3):541-549.

[29]. Verbalis JG, Mangione MP, Stricker EM. Oxytocin produces natriuresis in rats at physiological plasma concentrations. Endocrinology, 1991; 128(3):1317-1322.

[30]. Conrad KP, Gellai M, North WG, Valtin H. Influence of oxytocin on renal hemodynamics and sodium excretion. Ann N Y Acad Sci, 1993; 689:346-362.

[31]. Sjöquist M, Huang W, Jacobsson E, Skøtt O, Stricker EM, Sved AF. Sodium excretion and renin secretion after continuous versus pulsatile infusion of oxytocin in rats. Endocrinology, 1999; 140(6):2814-2818.
[32]. Brooks FP, Pickford M. The effect of posterior pituitary hormones on the excretion of electrolytes, in dogs. J Physiol, 1958; 142:468493.

[33]. Chan WY, Sawyer WH. Saluretic actions of neurohypophysial peptides in conscious dogs. Am J Physiol, 1961; 201:799-803.

[34]. Kostoglou-Athanassiou I, Treacher DF, Forsling ML. Is oxytocin natriuretic in man? J Endocrinol, 1994; 143(Suppl. O):39.

[35]. Conrad KP, Gellai M, North WG, Valtin H. Influence of oxytocin on renal hemodynamics and electrolyte and water excretion. Am J Physiol, 1986; 251:F290-F296.

[36]. Soares TJ, Coimbra TM, Martins AR, Pereira AGF, Carnio EC, Branco LGS, AlbuquerqueAraújo WIC, De Nucci G, Favaretto ALV, Gutkowska J, McCann SM, Antunes-Rodrigues J. Atrial natriuretic peptide and oxytocin induce natriuresis by release of cGMP. Proc Natl Acad Sci U S A, 1999; 96:278-283.

[37]. Baird S, Pickford M. The simultaneous occurence of certain changes in uterine and renal activity in dogs, and the role of oxytocin in these phenomena. J Physiol, 1958; 144:80-91.

[38]. Andersen SE, Engstrom T, Bie P. Effects on renal sodium and potassium excretion of vasopressin and oxytocin in conscious dogs. Acta Physiol Scand, 1992; 145:267-274.

[39]. Gabrielsson, J.L.; Weiner, D., Pharmacokinetic and Pharmacodynamic data analysis, Concepts and Applications, 2nd ed., Swedish Pharmaceutical Press, Stockholm, Sweden, 1997.

[40]. D’Argenio, D.Z.; Schumitzky, A., ADAPT II user's guide pharmacokinetic/ pharmacodynamic systems analysis software. Biomedical Simulations Resource, Los Angeles, CA, USA, 1997.

[41]. Gibaldi, M.; Perrier, D., Pharmacokinetics, 2nd ed., Marcel Dekker, Inc, New York, NY, USA, 1982.

[42]. Neter, J., Applied linear statistical models: regression, analysis of variance and experimental designs, Neter, J.; Wasserman, W.; Kutner, M.H., 3rd ed., Richard D. Irwin, Inc, Homewood, IL, U S A, 1990.

[43]. Bonate, P.L., Pharmacokineticphamacodynamic modeling and simulation. Springer, Inc, New York, NY, USA, 2005.

[44]. Kowalski WB, Diveky L, Mehendale R, Parsons M, Wilson L Jr. Effect of pregnancy on the metabolic clearance rate and the volume of distribution of oxytocin in the baboon. Am J Physiol, 1998; 274:E791-E795.

[45]. Fabian M, Forsling ML, Jones JJ, Lee J. The release, clearance and plasma protein binding of oxytocin in the anaesthetized rat. J Endocrinol, 1969; 43:175-189. 
[46]. Gimpl G, Farenholtz F. The oxytocin receptor system: Structure, function and regulation. Physiol Rev, 2001; 81(2):629-683.

[47]. Nakamura H, Itakuara A., Okamura M, Ito M, Iwase A, Nakanishi Y, Okada M, Nagasaka T, Mizutani S. Oxytocin stimulates the translocation of oxytocinase of human endothelial cells via activation of oxytocin receptors. Endocrinology, 2000; 141(12):44814485 .

[48]. Tsujimoto M, Hattori A. The oxytocinase subfamily of M1 aminopeptidases. Biochim Biophys Acta, 2005; 1751:9-18.

[49]. Guzzi F, Zanchetta D, Cassoni P, Guzzi V, Francolini M, Parenti M, Chini B. Localization of the human oxytocin receptor in calveolin-1 enriched domains turns the receptor-mediated inhibition of cell growth into a proliferative response. Oncogene, 2002; 21:1658-1667.

[50]. Arpin-Bott MP, Waltisperger E, Freund-Mercier MJ, Stoeckel ME. Two oxytocin binding subtypes in rat kidney: pharmacological characterization, ontogeny and localisation by in vitro and in vivo autoradiography. J Endocrinol, 1997; 153(1):49-59.

[51]. Costa-e-Sousa RH, Pereira-Junior PP, Oliveira PF, Olivares EL, Werneck-de-Castro JPS, Mello DB, Nascimento JHM, Campos-de-Carvalho AC. Cardiac effets of oxytocin: Is there a role for this peptide in cardiovascular homeostasis? Regul Pept, 2005; 132:107-112.

[52]. Han JS, Macda Y, Knepper MA. Dual actions of vasopressin and oxytocin in regulation of water permeability in terminal collecting duct. Am J Physiol, 1993; 265:F26-F34.

[53]. Wargent ET, Burgess WJ, Laycock JF, Balment RJ. Separate receptors mediate oxytocin and vasopressin stimulation of cAMP in rat inner medullary collecting duct cells. Exp Physiol,1999; 84:17-25.

[54]. Joo KW, Jeon US, Kim G-H, Park J, Oh YK, Kim YS, Ahn C, Kim S, Kim SY, Lee JS, Han JS. Antidiuretic action of oxytocin is associated with increased urinary excretion of aquaporin-2. Nephrol Dial Transplant, 2004; 19:2480-2486. 